\title{
FEM assessments on roofing constructive solutions applied to a twelfth century Romanesque church at Vall d'Aran (Spain)
}

\author{
A. Costa, G. Fortuny, J. Fabregat \& A. Royo \\ Predepartamental Unit of Architecture, \\ Rovira i Virgili University (Reus), Spain
}

\begin{abstract}
In the region of Vall d'Aran we find an ensemble of Romanesque churches with very particular formal and constructive characteristics. These buildings, most of them built during the twelfth century, have suffered various alterations through history. Their capacity to deform in many cases has put the balance of the masonry structure to the limit, forcing the introduction of stabilizing elements. The paper sets out a qualitative evaluation of the behaviour of the masonry structure under different loading hypothesis. The methodology combines the results of limit analysis of thrust lines and the Finite Element Method (FEM), focusing on the influence of the location of weights according to typical roofing systems.

The Church of Santa Eulària d'Unha has been chosen for the analysis. It is a church with a basilica plan floor, very common in the area, with large deformations of the masonry structure. The use of advanced techniques of indirect measurement has enabled a mapping with unprecedented detail. The exhaustive analysis of the registered deformations has allowed the identification of an inclination of up to $4.6 \%$ in the perimeter walls. The location of the loads of the roof over the masonry structure has a major influence on its stability, and restoration works often imply the intervention on this element. The paper presents a comparison between different solutions.

Keywords: FEM analysis, limit analysis, masonry, Vall d'Aran, Unha.
\end{abstract}




\section{Introduction}

Architecture heritage has been constantly modified through the centuries, adding or removing parts which used to cause a change in the loading conditions. Masonry structures are especially sensitive to these changes. The assessment of these structures in response to interventions is of great help in understanding their behaviour and improving technical solutions.

The present work is focused on a particular case, the Church of Santa Eularia d'Unha at Vall d'Aran. This region is located in the Spanish Pyrenees, in the north of Catalonia, and treasures a rich and varied heritage with a set of Romanesque churches characterized by the great deformations of their structure. They have been studied by many architects and historians, such as Josep Puig i Cadafalch (1867-1956) [1] or Joan Bassegoda Nonell (1930-2012) [2]. Also, documents and pictures state that Lluís Domenech i Montaner (1850-1923) brought architecture students in the early twentieth century.

Due to their great deformations, some of these churches have been modified, such as the church of Santa Maria d'Arties, which structure was already studied by Bassegoda Nonell [3], Villanueva [4], Saez [5] and Polo and Cots [6]. Another recent study performed by Costa et al. [7], is a direct precedent to the present paper.

According to the structural nature of masonry buildings, its stability depends largely on load distribution. It highlights the relevance of intervening in the roof of these constructions, since the application point of load is determinant. In this context, the behaviour of the structure of Santa Eulària d'Unha is assessed considering several roofing solutions.

\section{Case study: Santa Eulària d'Unha}

Santa Eulària d'Unha is a Romanesque church build at the end of the eleventh century. It is located on top of a rocky hill in the little village of Unha, at $9 \mathrm{~km}$ from Vielha. Throughout history, it has suffered several transformations, most of them due to the displacements of the masonry. There is very few documental evidence about these changes, but the historical context and the assessment of the masonry allows setting a general chronology.

The church has the traditional basilical plan with a central nave and two lateral naves. It is oriented east-west, with the apse in the east side (alpha-headmorning-birth) and the choir in the west side (omega-feet-evening-death). The central nave is covered with a barrel vault supported by six round pillars. Lateral naves are lower and covered by pointed half-vaults, supported by the pillars and the wall. The naves are separated longitudinally by rounded arches.

The main access to the building is located in the southern façade, where can be found most of the openings. The northern wall is completely blind, and three large buttresses were built at some time to balance the thrusts of the vaulting. In 1716 , the bell tower was built with a total height of $25 \mathrm{~m}$, supported over the west facade of the church, and regarding the roof, the marks on the masonry of almost three different inclinations reveal several changes. 
All these modifications have changed the stability conditions of the structure, altering the distribution of loads. These processes together with the settlement of the masonry through time have deformed the architectural elements. The measures are not constant, geometrical forms are irregular and neither pillars nor walls are aligned.

About materials, the church is basically built with little stones and lime mortar with low mechanical properties. The roof presents the typical solution with a timber frame and slate tiles, supported over the pillars and walls.

\section{Methodology}

The analysis of different roofing solutions and its influence on the behaviour of the masonry vaulted structure is performed through a combined methodology. The assessment of the equilibrium conditions of the structure is based on the widely developed principles of limit analysis [8-10] determining possible stable solutions of the structure through lines of thrusts. This type of study is especially helpful when visualizing whether the structure collapse mechanisms can be activated. Despite the method is of proved validity, it is limited to the assessment in two dimensions. It is possible to go a step further carrying out calculations by means of the Finite Elements Method (FEM). These enable to assess in three dimensions the distribution of inner strains within the entire structure, and visualize the displacements. Only qualitative results will be considered, referred exclusively to the response of the geometry of the structure. The aim of the assessment and the precision of the available data make no sense to raise an advanced calculation.

In the first place, an accurate geometrical survey of the structure is performed. Following, it can be carried out the structural assessment, which will be performed in two differentiable phases. The limit analysis enables the characterization of stability conditions of the current structure. The FEM calculation will complete the conclusions about the behaviour of the overall masonry structure under different load distributions. The described strategies are commonly used in the assessment of masonry structures [11-13].

\subsection{Geometrical survey}

The first phase of the assessment required an exhaustive survey of the current geometry of the church. The campaign was carried out during March and April of 2014. The methodology combined direct measurements and photogrammetric methods. This first survey was completed with the topographical data obtained with indirect measurements with a motorized Total Station. Several highresolution one-line profiles were obtained both for the vertical sections and the floor plan. Fig. 1 presents the current floor plan and the main sections of the church as a result of the survey.

The measures of the displacements detected in the most deformed profile are the following: the horizontal displacement of the south pillar is $2.5 \%(11.68 \mathrm{~cm}$ for a height of $4.65 \mathrm{~m})$, and in the north pillar is $4.6 \%(21.35 \mathrm{~cm}$ for a height of 

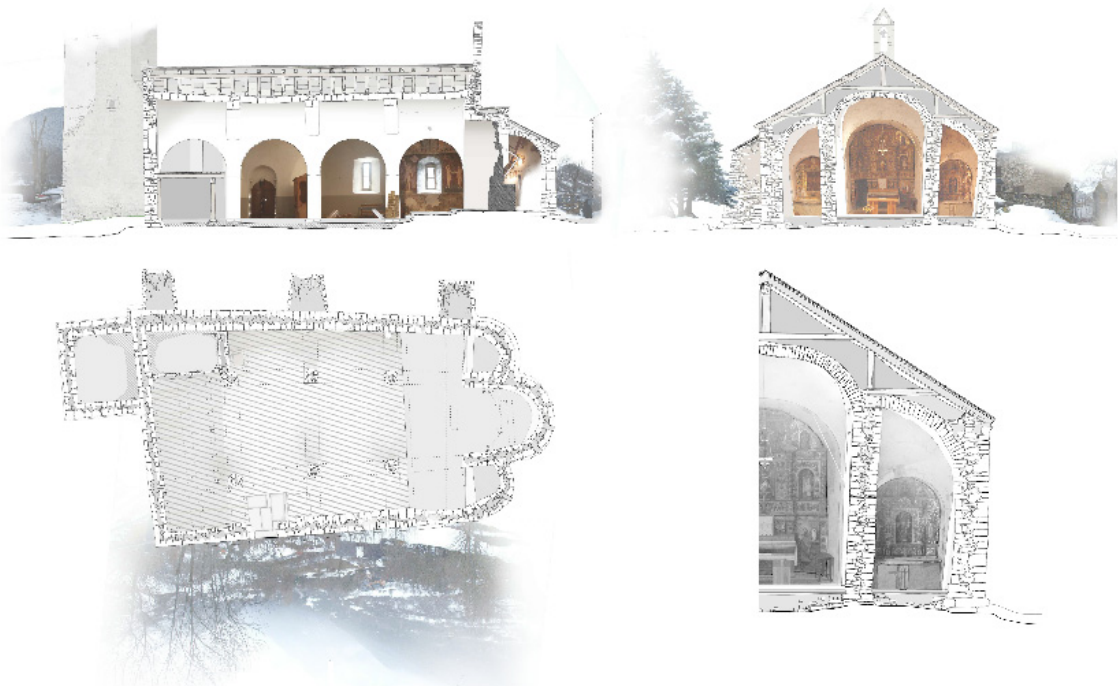

Figure 1: Longitudinal section, cross section, floor plan and detail of the masonry and roof solution.

$465 \mathrm{~cm})$. Settlement of the central vault is $15.63 \mathrm{~cm}$ for a span in the spring line of $454 \mathrm{~cm}$.

\subsection{Structural assessment}

\subsubsection{Limit analysis assessment}

The stability of the structure is assessed by means of two geometrical models. The current shape of the masonry and a theoretical initial shape before deformations occurred. This could be achieved by a drawing restitution process considering the supports have not changed its position in the ground and they were perfectly vertical.

Stability is analysed for both hypothetic and current shapes of the structure. The aim of this dual analysis is to determine if the initial shape was stable and the safety of the present model. Also it will evidence the differences between both models their stability conditions. The most deformed sections obtained from the Total Station survey are analysed for the current state. The specific weight of materials has been defined according to usual values. Thus, for masonry is $25 \mathrm{kN} / \mathrm{m}^{3}$ weight, and for the roofing is $1.5 \mathrm{kN} / \mathrm{m}^{3}$. The supports of the timber structure are placed following the description of study Case 1, described below.

\subsubsection{FEM assessment}

The survey enables building a 3D model of the church deformed shape with a Cad application. Mesh and calculation are performed with the program SalomeMeca, open source software from Linux [14, 15]. By means of the Mesh module, the mesh obtained has 360,395 tetrahedrons and 94,175 nodes (Fig. 3). Since the 
assessment is focused on the central nave, neither the apse nor the bell tower have been modelled.

Boundary conditions are defined for each roofing solution, and the cases are performed through the application of loads. Thus, groups of meshes are defined, setting the support points and the corresponding load distribution for each case.
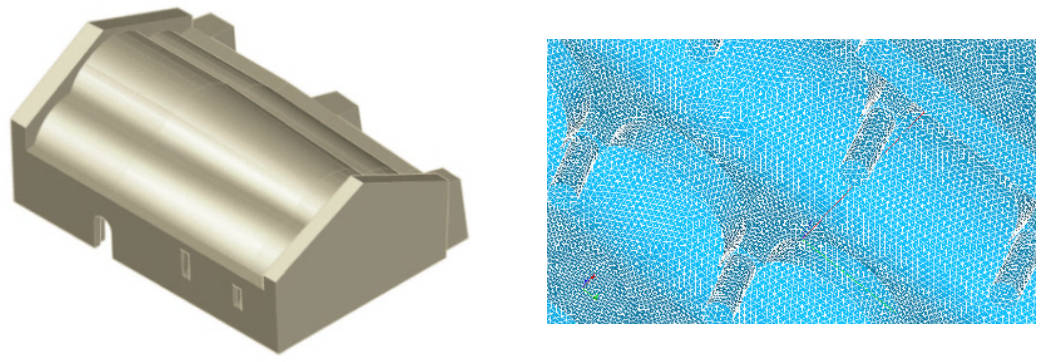

Figure 2: Cad 3D geometry and Mesh obtained.

The model takes into account the action of gravity and the weight of the roof. This last one has the aforesaid value of $1.5 \mathrm{kN} / \mathrm{m}^{3}$. Material parameters of the masonry are defined as follows: E: $3000 \mathrm{~N} / \mathrm{mm}^{2}$; Poisson Ratio: 0.23 ; specific weight: $25 \mathrm{kN} / \mathrm{m}^{3}$. These parameters are common for all the study cases. After defining the load distribution per each roofing solution, the calculation can be run. A linear-static FEM calculation is used in the Aster module. Thus the nonlinear behaviour of the material is not yet considered. The main objective of calculations at this stage is to set a qualitative comprehension of the distribution of loads according to the geometry, considering the masonry structure as a $3 \mathrm{D}$ solid.

\subsection{Study cases: roofing constructive solutions}

As introduced, the purpose is to determine the influence of the load distribution on the behaviour of the masonry structure, according to several roof solutions. The different study cases considered are presented below.

Case 0: as a preliminary test, the first hypothesis ignores the load of the roofing in order to determine stresses and deformations due to the own weight of the deformed structure.

Case 1: it reproduces the typical support system in this kind of churches. Several authors and interveners $[2,6]$ have described it as a timber roof with punctual supports on the longitudinal axis of the central nave, the centre of pillars and walls (fig. 3a). This hypothesis has been considered for both the Limit Analysis and the FEM analysis.

Case 2: load distribution in this case is similar to the Case 1, but here the supports are placed over the middle of the central nave, instead of the pillars (fig. 3b). The described traditional roofing system (Case 1), has often been modified by removing the roofing support located on the longitudinal central axis of the central nave in order to reduce thrusts [5]. 
Case 3: the roofing stands upon linear supports located along every cross section with pillars (fig. 3c). Masonry ribs would be built over the cross sections. The calculation will only consider the load distribution of the solution, and not the bracing effect of the ribs

Case 4: this case considers the effect of covering the upper vault surface with a uniform load (fig. 3d). This might be reminiscent of heritage interventions in which the roofing solution consisted of covering the extrados with a thin uniform layer of light reinforced concrete. This case focuses on the effect of the load in the overall masonry structure, and the possible favourable effect in the stiffness of the vaults is not considered.
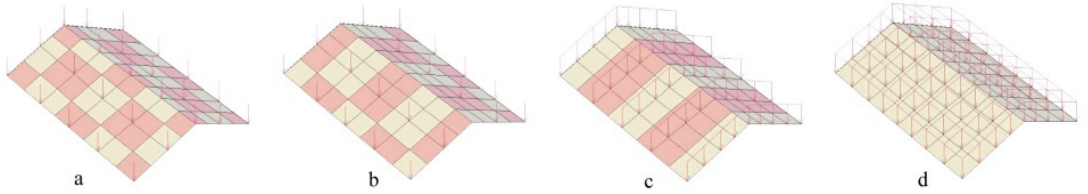

Figure 3: Case studies: load distribution.

\section{Results}

\subsection{Limit analysis}

Determining the situation of the church in terms of stability requires performing both initial section and current deformed section limit analysis.

In the first place, the analysis of the theoretical initial geometry revealed that the situation of stability of the church was already delicate. It is possible to draw a range of possible solutions considering various hypotheses, despite the fact that they are near the limit of the masonry (Fig. 4a). However, according to the principles of limit analysis [6], if ever a single line of thrust can be found within the masonry, the structure will be stable.

When analysing the current deformed shape it could be observed that lines of thrusts tended to escape its limits in the base of the pillars. This circumstance lead to the conclusion that extra load in the upper side of the vaults had been dismissed in the hypothesis of the current roofing solution. Increasing the weight of the lateral vaults had a great redirecting effect on the thrust lines (Fig. 4b), and it was possible, as in the initial shape, to find a valid range of solutions of thrust lines for the current state of Santa Eulària.

In both cases, finding thrust lines within the section of the central vault has been particularly struggling because of its lowered geometry. In addition, the slenderness of the pillars was not favourable. The results highlight the importance of the loads applied on the upper side of the lateral half vaults. This set of constructive elements work as a buttressing system for the central lowered vault, counteracting the large horizontal thrusts.

By comparing results of the analysis with the church itself, it can be proved that those zones where lines of thrust approach the boundaries of the section are changed into physical cracks. 

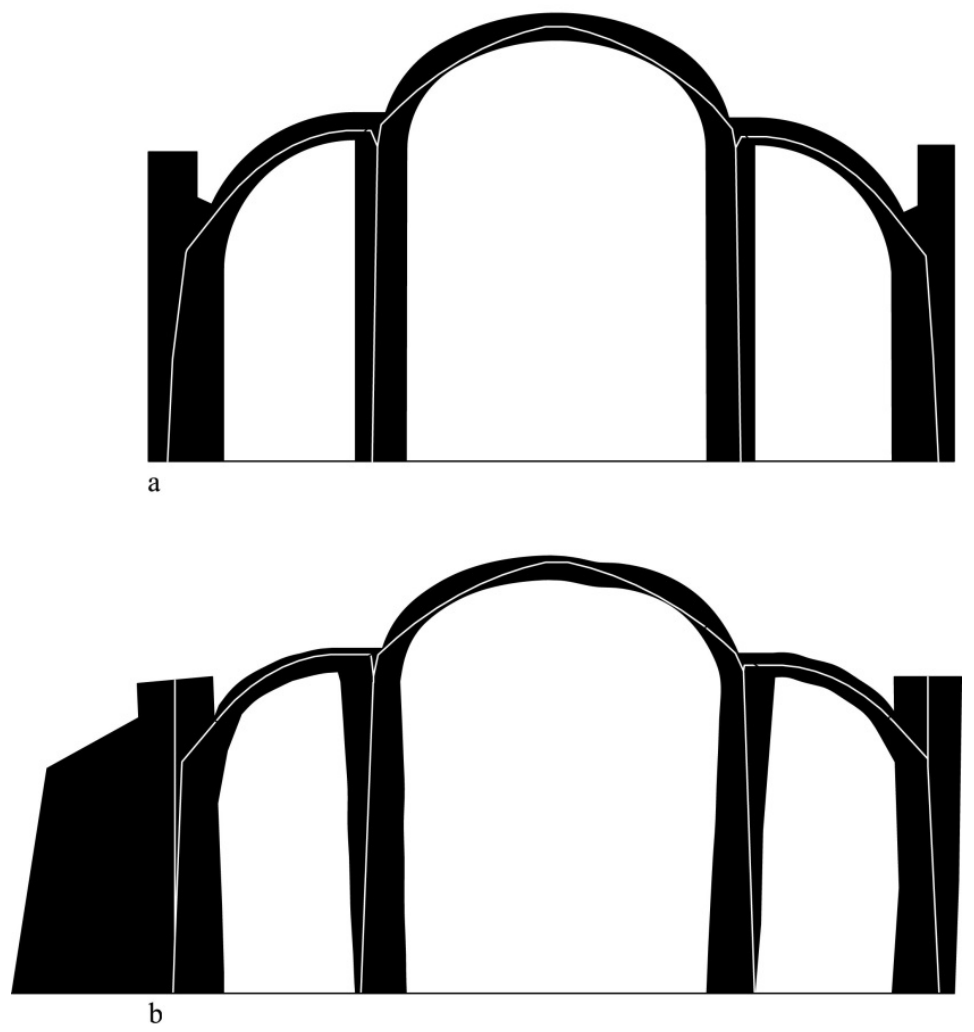

Figure 4: Limit analysis results. a) theoretical initial shape; b) current deformed shape

\subsection{FEM Analysis}

The different load distributions described in (Cases 1-4) are tested using the deformed shape of the church, obtaining the distribution of strains and displacements.

Loads are applied as a pressure on the selected external faces of the meshed solid elements. This procedure does not consider the stiffening effect that some of the solutions could introduce in the overall behaviour. Otherwise, this analysis gives clues to the reaction of the deformed structure to several changes. This kind of analysis leads to qualitative conclusions about the overall behaviour of the structure, and opens the door to further and more precise calculations that may consider the nonlinear behaviour of the material.

Graphical results are summarized in Fig. 5, showing scalar maps of strains and displacements for each case. Case 0 only considers the own weight of the masonry structure, not taking into account any roofing load. The results fully match the current cracks and deformations observed in the church, and are also 
coherent with the results obtained from the Limit Analysis assessment for the current deformed state.

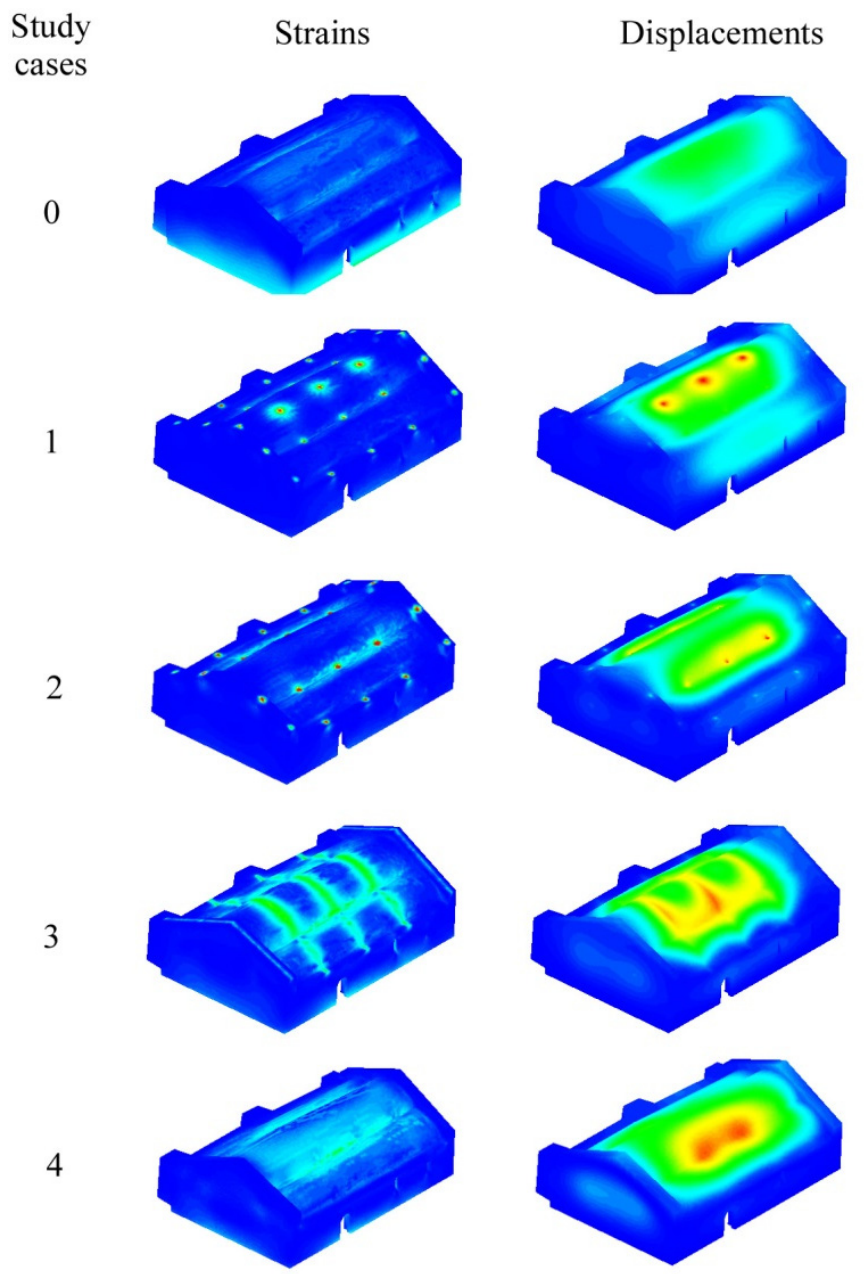

Figure 5: Results of the FEM calculation.

In general terms, major strains over the vault coincide with the location of supports, as well as displacements. In case 1, displacements are larger at the top of the central nave due to the location of one of the roofing supports on it. In the south wall the displacements are larger compared to the other cases and related to the values in the vaulting. Unlike the north wall, it has no buttresses and several windows have been opened on it through time. In the other hand, Case 2 shows a more homogeneous distribution of stresses and displacements. The lack 
of any support over the central nave concentrates strains on the pillars and walls, and the displacements in the south wall are smaller.

Unlike the aforesaid cases, the displacements in the south wall are unappreciable. In Case 3, strains not only concentrates on pillars but on every cross section loaded. Displacements are located along the mentioned cross sections, specially affecting the central vault. Even though the load supported by each section is almost the same, the central ones suffer greater displacements because of the perimeter walls increase the stiffness of the structure at its ends. Finally, Case 4 shows the effect of loading uniformly the upper surface of the vaults. Strains gradient is more consistent than in other cases, and displacements follow the same behaviour observed in Case 3 with greater movements in the central area.

\section{Discussion and further research}

Limit Analysis determined that the church was stable in its initial geometry, as well as in the current deformed shape. This conclusion set the following question: how and why the initial stable masonry structure has become unstable? Material with poor mechanic properties had been used for the construction of these churches. Evidence of this has been found in recent restoration works of the perimeter walls. This could explain the assumption of great geometric variations from a hypothetical initial model in the permanent and unfinished process of settlement of the building.
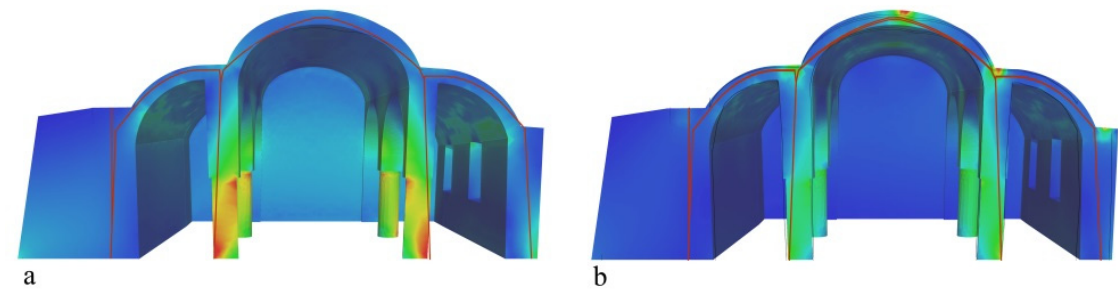

Figure 6: Superposition of limit analysis and FEM: a) gravity load; b) case 1 loads.

Whether Limit Analysis can present the key frames of the stability of the structure (initial - final section), FEM can help to explain the reasons of the process of deformation. Stiffness is a fundamental and influencing factor that determines FEA results, as indicated by Oñate [16] and Zienkiewicz and Taylor [17]. The assessment on Santa Eulària d'Unha revealed how the variations on stiffness due to the disposition of constructive elements influence deformations and can lead to structure cracking.

The asymmetric cross section of the church reveals larger deformations in the south wall. Despite a buttress improves the stability of a structure, the greater stiffness of the opposite north wall held by the three buttresses can increase the deformation process in the opposite wall. This suggests the idea of stiffness being considered as a tangible parameter which has to be understood in the 
overall structure, and which can be related to classical statements about beauty, symmetry or equilibrium.

It has been a deductive non-destructive procedure to deduce a coherent actual roofing composition. Further research will focus on considering the non-linear behaviour of the material and introducing the mechanics of damage [18, 19]. This methodologies are currently well developed, and several authors and researchers are already using numerical analysis to complement their research on architectural heritage intervention, such as Lluis i Ginovart et al. [20] or Martínez et al. [21] among many others. In further research, this will be essential for reaching more accurate results and setting new investigation strategies.

\section{Conclusions}

The roofing of a masonry structure is a key constructive element that has a direct effect on its stability. According to this, the objective of the paper has been to test several hypothesis of load disposition, reproducing typical roofing constructive solutions. This process required developing a methodology, which enabled to understand the response of the masonry structure to the several input situations. Thus, the methodology used combined Limit Analysis and Finite Element Analysis.

Results obtained in the limit analysis revealed that, according to the principles of the procedure, the structure should have been stable, and highlighted the importance of the presence of loading on the extrados of the lateral half vaults to absorb the important horizontal thrust caused by the lowered geometry of the central vault.

The FEM revealed that the most favourable loading distribution for Santa Eulària d'Unha church are cases 1 and 2. Displacements and strains are minor compared to the other cases. Note that any of these two cases deposit too much load on the central lowered vault, and results are coherent with the limit analysis assessment.

Despite Limit Analysis and especially FEM are not applied exhaustively; it is unquestionable that both analysis refer to essential, but differentiable aspects on the behaviour of masonry. It has been proved that its fluent and focused application may be of great help for planning heritage architectural interventions.

About the Church of Santa Eularia d'Unha, with large deformations, stands out as an example of a masonry building challenging the boundaries of stability. Like most of the churches in the Vall d'Aran, it evidences the importance of defining an analysis methodology based on suitable procedures to understand the behaviour of the masonry structure.

\section{Acknowledgements}

The authors would like to acknowledge Bisbat d'Urgell and Conselh Generau d'Aran, for kindly opening the door of their precious churches to our research on architectural heritage. 


\section{References}

[1] Puig i Cadafalch, J., Les iglesies romàniques amb cobertes de fusta de les Valls De Bohí y d'Aran. Anuari de l'Institut d'Estudis Catalans: MCMVII, pp. 119-136, 1908.

[2] Bassegoda Nonell, J., Estética expresionista de la arquitectura románica lombarda en Catalunya como consecuencia de las deformaciones formales y estructurales de las iglesias. De Re Restauratoria. Vol. II. Cátedra Gaudi. UPB. Barcelona, pp. 33-64, 1974.

[3] Bassegoda Nonell, J., La Iglesia de Santa María de Arties, barroca y racionalista. Un templo sin cimientos. La Vanguardia Española. Jueves 28 de septiembre, p. 51, 1972.

[4] Villanueva, L., Las bóvedas de cañon. De Re Restauratoria. Vol. II. Cátedra Gaudi. UPB. Barcelona, pp. 145-158, 1974.

[5] Saez, G. Primera fase del proyecto de restauración de la Iglesia de Santa María de Artíes en el Valle de Arán (Lérida). Cuadernos de Arquitectura y Urbanismo, $\mathrm{N}^{\mathrm{o}} 116$, pp. 63-71, 1976.

[6] Polo and Cots, Santa Maria d'Arties (Naut Aran, Val d'Aran): Un exemple integrau a nivèu de restauracion d'un monument a compdar des entresenhes arqueologiques. Cicle de conferències patrimoni arqueològic $i$ arquitectònic a les Terres de Lleida. Departament de Cultura i Mitjans de Comunicació, pp. 75-103, 2009.

[7] Costa A., Lluis i Ginovart J., Fortuny G. Large deformations on XIIth Century Romanic churches at la Val d'Aran (Spain) Proc. of the $9^{\text {th }}$ International Masonry Conference, Guimaraes, p. 221, 2014.

[8] Heyman, J. The stone skeleton: structural engineering of masonry architecture, Cambridge University Press: Cambridge, 1964.

[9] Huerta, S., Mechanics of masonry vaults: the equilibrium approach. Proc. of the $3^{\text {rd }}$ International Seminar Historical constructions 2001, Possibilities of numerical and experimental techniques, P.B. Lourenço \& P. Roca (Eds.), 2001.

[10] Block, P., DeJong, M. \& Ochsendorf, J. As Hangs the Flexible Line: Equilibrium of Masonry Arches. Nexus Network Journal, 8(2), pp. 13-24, 2006.

[11] Roca, P., Cervera, M., Gariup, G., Pelà, L., Structural Analysis of Masonry Historical Constructions. Classical and Advanced Approaches, Archives of Computational Methods in Engineering 17, pp. 299-325, 2010.

[12] Roca, P., \& Lodos, J. C., Análisis estructural de catedrales góticas. OP: Revista del Colegio de Ingenieros de Caminos, Canales y Puertos 56, pp. 38-47, 2001.

[13] Lourenço, P. B.: Analysis of historical constructions: From thrust-lines to advanced simulations. Historical constructions, pp. 91-116, 2001.

[14] Code Aster and Salome Meca website, www.code-aster.org

[15] Salome Meca Platform, www.salome-platform.org

[16] Oñate, E. Cálculo de estructures por el Método de los elementos Finitos. Análisis estàtico lineal, CIMNE Publications: Barcelona, 1995. 
[17] Zienkiewicz, O.C. and Taylor, R.L., El método de los elementos finitos (2), mecánica de sólidos. CIMNE Publications: Barcelona, 2010.

[18] Betti, M., Bartoli, G., Corazzi, R. \& Kovac Evic, V. Strumenti Open Source per l'ingegneria strutturale. Modellazione meccanica non lineare di edifice in muratura. Bollettino degli Ingegneri, 2013.

[19] Mazars, J., Application de la mécanique de l'endommagement au comportament non linéaire et la rupture du béton de structure, $\mathrm{PhD}$ Thesis, Université Paris VI, 1984.

[20] Lluis i Ginovart, J., Costa, A., Fortuny, G., Assessment and restoration of a masonry dome in the cathedral of Tortosa enclosure. STREMAH XIII. Structural studies, repairs and maintenance of Heritage Architecture XIII. Section 8: Heritage masonry. pp. 391-401, 2013.

[21] Martínez, A., Durà, A., de Mazarredo, L., Llopis, V., Análisis estructural de la cúpula de la iglésia de Todoella. ARCHÉ, Publicación del Instituto Universitario de Restauración del Patrimonio de la UPV, 4-5, pp. 439-446, 2010. 